\title{
MINAT BELAJAR DAN LINGKUNGAN KAMPUS SEBAGAI DETERMINASI HASIL BELAJAR MAHASISWA
}

\author{
Rendra Gumilar; Riki Yakub Pirdaus \\ Universitas Siliwangi, Indonesia \\ E-mail:rendragumilar@unsil.ac.id
}

\begin{abstract}
The low learning outcomes of Economic Education students is the reason why this research was conducted, so that it will determine the determinants of learning outcomes. The sample of this study was the Economics Education Students of the Teaching and Education Faculty of Siliwangi University, Tasikmalaya class of 2018 with a total of 112 people. The research method in this study was a survey with a rating scale questionnaire data collection tool and data analysis using multiple linear regression techniques using SPSS 25. The results showed interest in learning, the campus environment, and learning outcomes included in the medium category, to influence learning interest and the campus environment significant effect on student learning outcomes by $41.7 \%$ and $58.3 \%$ influenced by other factors.
\end{abstract}

Keywords: learning outcomes; campus environment; interest in learning

Abstrak. Rendahnya hasil belajar mahasiswa Pendidikan Ekonomi menjadi alasan mengapa penelitian ini dilakukan, sehingga akan mengetahui faktor determinasi hasil belajar. Sampel penelitian ini adalah Mahasiswa Pendidikan Ekonomi Fakultas Keguruan dan Ilmu Pendidikan Universitas Siliwangi Tasikmalaya angkatan 2018 dengan jumlahnya 112 orang. Metode penelitian dalam penelitian ini adalah survey dengan alat pengumpul data angket model rating scale dan analisis data menggunakan teknik regresi linier berganda menggunakan SPSS 25. Hasil penelitian menunjukan minat belajar, lingkungan kampus, dan hasil belajar termasuk kategori sedang, untuk pengaruh minat belajar dan lingkungan kampus berpengaruh signifikan terhadap hasil belajar mahasiswa sebesar $41,7 \%$ dan $58,3 \%$ dipengaruhi oleh faktor lain.

Kata Kunci: hasil belajar, lingkungan kampus, minat belajar

Permalink/DOI: https://doi.org/10.15408/mimbar.v36i2.14185 


\section{Pendahuluan}

Pendidikan merupakan hak setiap manusia, didalam pendidikan tentunya ada proses belajar. Belajar merupakan upaya sadar yang dilakukan seseorang agar dapat mencapai hasil yang diharapkan yaitu terjadi perubahan perilaku, yang secara nyata melalui proses belajar dan pembelajaran. Belajar merupakan pengalaman yang menunjukkan suatu proses runtun yang dialami oleh setiap orang, belajar tidak hanya dilakukan di sekolah saja, akan tetapi dalam kehidupan sehari-hari juga belajar juga bisa dilaksanakan.

Tujuan dari adanya kegiatan belajar bukanlah penguasaan hasil, melainkan perubahan tingkah laku ke arah yang lebih baik (Hamalik, 2010). Hasil belajar digambarkan sebagai perubahan perilaku yang dapat di ukur melalui proses pengamatan, pembuktian, dan pengukuran atas kemampuan atau hasil yang diperoleh anak didik. Hasil belajar merupakan gambaran atas kemampuan siswa yang diperolahnya melalui pengalaman belajar di sekolah (Nemeth \& Long, 2012; Molstad\&Karseth, 2016).

Dalam kegiatan belajar tentunya ada output yang dihalsilkan yang dinamakan hasil belajar. Terdapat banyak faktor yang yang mempengaruhi hasil belajar baik faktor internal yang menyangkut baik jasmani maupun rohani dan faktor eksternal termasuk faktor lingkungan (Syaodih, 2009). Siswa yang memiliki dukungan internal dan eksternal yang baik tentunya diduga memiliki kapabilitas yang lebih untuk meraih hasil belajar yang bagus dan begitupun sebaliknya jika siswa ataupun mahasiswa tidak memiliki dukungan penuh dari faktor internal dan eksternalnya maka akan berpengaruh terhadap motivasi belajarnya yang bisa berdampak terhadap hasil beajar yang didapat.

Setiap mahasiswa tentunnya memiliki karateristik yang berbeda-beda dan tidak dapat disamakan. Dukungan internal dan eksternalnya juga akan sangat berbeda setiap orangnya. Hal ini dibuktikan dengan bagaimana mahasiswa tersebut memiliki motivasi belajar yang berbeda-beda dan juga hasil beajar yang dicapai berbeda-beda pula. Pada kenyataanya hasil belajar ataupun prestasi belajar mahasiswa Pendidikan Ekonomi Univesitas Siliwangi ada dalam kategori rendah, dan hal ini harus dicari tahu apa akar penyebabnya.

Hasil belajar yang rendahtentunya tidak boleh dibiarkan, karena hasil belajaradalah orientasi pengalaman belajarnya dari kegiatan pembelajaran yang diikutinya (Nemeth \& Long, 2012; Molstad \& Karseth, 2016). Semua orang memiliki motivasi yang ada pada dirinya, dan mahasiswa juga memiliki motivasi belajar yang menjadi faktor internal yang ada pada dirinya. Minat belajar merupakan semangat yang ada pada diri mahasiswa yang akan diteliti bagaimana pengaruhnya terhadap hasil belajar. Sedangkan faktor eksternal yang dimiliki mahasiswa salah satunya adalah lingkungan kampus, hal ini akan diteliti bagaimana pengaruhnya terhadap hasil belajar.

\section{Metode}

Dalam penelitian ini metode yang digunakan adalah survey. Metode survey merupakan metode penelitian ini yang dimaksudkan untuk mengumpulkan informasi faktual melalui penggunaan 
kuesioner atau angket. Sampel dalam penelitian ini menggunakan sampel jenuh dimana seluruh populasi dalam penelitian diambil menjadi sampel. Populasi dalam penelitian ini adalah seluruh mahasiswa Pendidikan Ekonomi angkatan 2018 FKIP Universitas Siliwangi Tasikmalaya yang berjumlah 120 mahasiswa. Variabel dalam penelitian ini terdapat 3 variabel dengan rincian 2 variabel bebas yaitu minat belajar (X1) dan lingkungan kampus (X2), dan 1 variabel terikat yaitu hasil belajar (Y).

Data dalam penelitian ini didapatkan dari hasil ataupun angket model rating scale yang dibagikan kepada sampel. Untuk mengukur persepsi mahasiswa akan minat belajar diukur dengan indikator berupa perasaan senang dalam belajar, perhatian dalam belajar, ketertarikan,dan partisipasi. Untuk mengukur kualitas lingkungan kampus dapat diukur dengan indikatornya yaitu metode mengajar, kurikulum, relasi guru dengan mahasiswa, relasi mahasiswa dengan mahasiswa, disiplin sekolah, alat pelajaran, waktu sekolah, standar pelajaran, keadaan gedung, metode belajar, dan tugas rumah. Sedangkan untuk mengukur hasil belajar mahasiswa akan diukur berdasarkan nilai Ujian Akhir Semester Mata Kuliah Statistika. Analisis data untuk melihat pengaruh minat belajar dan lingkungan kampus terhadap prestasi belajar mahasiswa menggunakan teknik regresi linier berganda dengan rumus:

$$
\mathrm{Y}=\mathrm{a}+\mathrm{bX} 1+\mathrm{bX} 2+\mathrm{e} .
$$

Keterangan:

Y : Hasil Belajar

X1 : Minat Belajar

$\mathrm{X} 2$ : Pengetahuan Awal Siswa

a : Konstanta

$\mathrm{b}:$ Koefisien

\section{Hasil Penelitian dan Pembahasan}

Didalam penelitian ini sampelnhya adalah mahasiswa Pendidikan Ekonomi angkatan 2018 yang berjumlah112 mahasiswa dengan rincian kelas A 40 orang, kelas B 39 orang, dan kelas C 33 orang. Berdasarkan hasil pengamatan langsung dan juga hasil pengolahan data kuisioner bahwa minat belajar dalam kegiatan belajar mata kuliah Statistika mahasiswa ada pada ketgori sedang, karena distriusi frekuensinya terdapat pada level sedang. Berikut pada tabel 1 deskipsi minat belajar.

Tabel 1. Deskripsi Minat Belajar

\begin{tabular}{ccc}
\hline Kriteria Minat & Frekuensi & Persentase \\
\hline Tinggi & 28 & $25 \%$ \\
Sedang & 72 & $64 \%$ \\
Rendah & 12 & $11 \%$ \\
Jumlah & 112 & $100 \%$ \\
\hline
\end{tabular}

Berdasarkan Tabel 1 menjelaskan bahwa minat belajar mahasiswa pendidikan ekonomi harus lebih ditingkatkan lagi agar mahasiswa pendidikan ekonomi dapat memiliki motivasi belajar yang 
tinggi. Hal ini karena rata-rata dari total keseluruhan sudah mencapai 64\% yang memiliki jiwa minat belajar yang sedangi, sedangkan untuk mahasiswa yang memiliki minat belajar yang tinggi hanya 25,5\%, dan sisanya ada pada ketegori rendah sebesar 11\%. Deskripsi lingkungan kampus didapat dari hasil pengolahan data kuisioner yang dibagikan kepada responden. Berikut pada tabel 2 deskripsi lingkungan kampus.

Tabel 2. Deskripsi Lingkungan Kampus

\begin{tabular}{ccc}
\hline Kriteria Minat & Frekuensi & Persentase \\
\hline Tinggi & 42 & $38 \%$ \\
Sedang & 60 & $54 \%$ \\
Rendah & 10 & $9 \%$ \\
Jumlah & 112 & $100 \%$ \\
\hline
\end{tabular}

Berdasarkan Tabel 2 bahwa lingkungan kampus termasuk dalam kategori sedang dengan jumlah frekuensi 60 dari 112 mahasiswa, dengan persentase 54\%. Artinya adalah kualitas lingkungan kampus perlu ditingkatkan baik berupa sarana dan prasarana, kurikulum yang up to date, kualitas kegiatan pembelajaran, ruangan kelas yang nyaman, serta fasilitas pendidikan yang mumpuni. Jika kualitas lingkungan kampus tinggi tentunya secara tidak langsung akan mempengaruhi motivasi belajar mahasiswa dikampus untuk bisa mencapai hasil belajar yang maksimal serta yang diinginkan. Untuk deskripsi hasil belajar mahasiswa Pendidikan Ekonomi pada Mata Kuliah Statistika dapat dilihat pada Tabel 3.

Tabel 3. Deskripsi Hasil Belajar

\begin{tabular}{ccc}
\hline Kriteria Minat & Frekuensi & Persentase \\
\hline Tinggi & 30 & $27 \%$ \\
Sedang & 70 & $63 \%$ \\
Rendah & 12 & $11 \%$ \\
Jumlah & 112 & $100 \%$ \\
\hline
\end{tabular}

Berdasarkan Tabel 3 bahwa hasil belajar mahasiswa Pendidikan Ekonomi pada Mata Kuliah Statistika ada pada kategori sedang dengan jumlah frekuensi sebanyak 70, dengan persentase 63\%. Sedangkan 27\% termasuk kategori tinggi dan 11\% termasuk pada kategori rendah. Artinya masih terdapat banyak PR agar bisa meningkatkan hasil belajar mahasiswa. Setelah data penelitian diolah, selanjutnya data dianalisis menggunakan SPSS 25 untuk mengetahui bagaimana pengaruh minat belajar dan lingkungan kampus terhadap hasil belajar mahasiswa. Berikut ini adalah output analsis SPSS 25 bagimana kontribusi variabel bebas yang diteliti terhadap variabel terikat.

Tabel 4. Kontribusi variabel Minat Belajar dan Lingkungan Kampus terhadap Hasil Belajar

\begin{tabular}{cccc}
\hline $\mathrm{R}$ & R-Square & Adjusted Squared & Sig.F. Change \\
\hline $\mathbf{0 , 6 4 6}$ & 0,417 & 0,265 & 0,000 \\
\hline
\end{tabular}


Berdasarkan Tabel 4 bahwa nilai $\mathrm{R}$ Square adalah 0,417 yang artinya kontribusi variabel minat belajar (X1) dan lingkungan kampus (X2) terhadap hasil belajar (Y) adalah 41,7\% dan 58,3\% dipengaruhi oleh faktor lain. Berikut ini adalah tabel nilai koefisien antar keterkaitan variabel:

Tabel 5. Nilai Koefisien antar Keterkaitan Variabel

\begin{tabular}{lll}
\hline Variabel & t hitung & Sig-t \\
\hline Minat Belajar & 3,751 & 0,000 \\
Lingkungan Kampus & 4,241 & 0,000 \\
\hline
\end{tabular}

Berdasarkan Tabel 5 bahwa hubungan minat belajar terhadap hasil bejalar mahasiswa berpengaruh signifikan karena nilai signifikansi dari t hitung yaitu $0,000<0,05$, dan hubungan lingkungan kampus terhadap hasil belajar mahasiswa berpengaruh signifikan karena nilai signifikansi dari t hitung yaitu $0,000<0,05$. Dan selain itu minat belajar dan lingkungan kampus berpengaruh secara simultan atau bersama-sama terhadap hasil belajar mahasiswa karana berdasarkan Tabel 4 bahwa nilai signifikansi F yaitu $0,000<0,005$.

Deskripsi dari setiap variabel dalam penelitian ini memiliki sinergitas bagaimana minat belajar yang termasuk dalam kategori sedang mempengaruhi juga hasil belajar mahasiswa yang ada pada level sedang. Begitupun juga lingkungan kampus yang memiliki kartegori sedang mempengaruhi hasil belajar nmahasiswa yang ada pada level sedang juga. Semakin bagus atau tinggi minat belajar maka semakin tinggi pula hasil belajar mahasiswa yang dicapai, dan juga semakin bagus lingkungan kampus tempat belajar mahasiswa makan akan berpengaruh juga terhadap hasil belajar yang tinggi.

Dalam kenyatannya dalam dunia pendidikan saat ini adalah bagaimana minat belajar ataupun motivasi belajar seorang siswa ataupun mahasiswa tidak merata. Mahasiwa atau siswa dengan latar belakang yang bervariasi akan sangat berpengaruh. Hal ini menjadi pekerjaan rumah untuk semua pihak karena jika seorang anak dibiarkan untuk tidak memiliki semangat belajar maka akan sangat berbahaya terhadap masa depannya dan akan mempengaruhi kualitas pendidikan itu sendiri. Banyak sekali faktor yang mempengaruhi minat belajar seseorang dan diantaranya adalah keluarga dan juga teman sebaya. Jika kedua faktor tersebut mendukung penuh dengan keinginan seseorang baik siswa ataupun mahasiswa maka tentunya mereka akan memiliki minat belajar yang tinggi yang tentunya bisa berdampak langsung terhadap hasil belajar yang dicapainya.

Di sisi lain lingkungan kampus juga sangat berpengaruh terhadap hasil belajar mahasiwa. Jika kualitas kampus sangat baik dari sisi kualitas dosen, kualitas kurikulum, kualitas sarana dan prasarana, metode belajar yang baik, progran-program yang membuat mahasiswa bisa berfikir kritis dan bisa berdaya saing dengan mahasiswa kampus lain, maka tentunya hasil belajarnya juga akan bagus dan akan berdampak bagus terhadap kualitas pendidikan kampus tersebut. Jika lingkungan kampus tidak menyediakan apa yangdibutuhkan mahasiswa seperti fasilitas perpustakan yang mumpuni, ruangan kelas yang bagus dan nyaman serta, program kampus yang kurang mendukung kreatifitas mahasiswa, tentunya akan berdampak terhadap minat belajar siswa dan tentunya mempengaruhi semangat yang akan berdampak terhadap capaian belajar mahasiswa. 
Universitas Siliwangi yang telah menginjak 5 tahun sebagai perguruan tinggi negeri (PTN) masih dalam proses regenerasi untuk perbaikan kualitas sarana dan prasaran kampus dan tentunya kualitas para pendidik untuk bisa menjadi kampus yang memiliki kualitas pendidikan yang baik. Jurusan Pendidikan Ekonomi Fakultas Keguruan dan Ilmu Pendidikan saat ini terus berusaha untuk menigkatkan kualitas pendidikannya agar prestasi mahasiswanya bisa bagus dan mampu berdaya saing dengan jurusan lain, bahkan kampus lain. Peningkatan kualitas seluruh dosen, kualitas sarana prasarana dan perbaikan kurikulum yang up to date terhadap perkembangan zaman selalu dilaksanakan, hal ini dilakukan agar mahasiswa pendidikan ekonomi memiliki semangat belajar yang tinggi. Dalam penelitian ini kontribusi variabel minat belajar dan juga lingkungan kampus terhadap hasil belajar mata kuliah Statistika Mahasiswa Pendidikan Ekonomi FKIP Universitas Siliwangi adalah 41,7\% dan untuk $58,3 \%$ dipengaruhi oleh banyak faktor lain yang tidak diteliti dalam penelitian ini.

Hasil analisis dalam penelitian ini juga diperkuat dengan teori belajar Gagne bahwa pretasi belajar atau hasil belajar siswa ataupun mahasiswa dipengaruhi kondisi external, internal (Dimyati \&Mudjono, 2009:10). Kondisi internal dalam penelitian ini adalah minat belajar sedangkan kondisi eksternalnya adalah lingkungan kampus. Hasil dalam penelitian ini juga selaras dengan para peneliti terdahulu. Prima Sadewa (2018) melakukan penelitian dengan judul" Pengaruh Lingkungan Kampus dan Motivasi Mahasiswa Terhadap Prestasi Belajar Mahasiswa S1 Akuntasi Universitas Malang”. Dan hasil penelitian ini adalah bahwa terdapat pengaruh lingkungan kampus terhadap prestasi belajar sebesar $35,15 \%$ dan terdapat pengaruh motivasi terhadap prestasi belajar sebesar $51,9 \%$.

\section{Penutup}

Berdasarkan pembahasan dan analisis data bahwa minat belajar, lingkungan kampus, dan juga hasil belajar Mahasiswa Pendidikan Ekonomi Fakultas Kegururan dan Ilmu Pendidikan Univesitas Siliwangi termasuk pada kategori sedang. Dan hasil penelitian ini juga menunjukan bahwa minat belajar dan juga lingkungan kampus menjadi determinan hasil belajar mahasiswa secara bersama-sama atau simultan.

Agar hasil belajar mahasiswa Pendidikan Ekonomi meningkat tentunya banyak PR yang harus dibenahi baik itu peningkatan lingkungan kampus yang mencakup banyak hal seperti kualitas dosen, kualitas kampus, dan tentunya kualitas kurikulum yang sejalan dengan perkembangan zaman, serta tentunya pihak Jurusan ataupun Kampus membuat sebuah program yang bagus untuk bisa membuat mahasiswa memiliki motivasi belajar sangat tinggi yang akan berpengaruh terhadap hasil belajar.

\section{Daftar Pustaka}

Dimyati dan Mudjiono. (2009). Belajar dan Pembelajaran. Jakarta: Rineka Cipta

Hamalik, Oemar. (2011). Kurikulum dan pembelajaran. Jakarta: Bumi Aksara 
Molstad, C. E., \& Karseth, B. (2016). National Curricula in Norway and Finland: The Role of Learning Outcomes. European Educational Research Journal , 15 (3), 329-344.

Nemeth, J., \& Long, J. G. (2012). Assessing Learning Outcomes in U.S. Planning Studio Courses. Journal of Planning Education and Research, 32 (4), 476-490

Sadewa, P. (2018). Pengaruh Lingkungan Kampus Dan Motivasi Mahasiswa Terhadap Prestasi Belajar Mahasiswa S1 Akuntansi Universitas Pamulang. Jurnal Madani: Ilmu Pengetahuan, Teknologi, Dan Humaniora, 1(1), 211-234. https://doi.org/10.33753/madani.v1i1.11

Sukmadinata, Nana Syaodih. 2009. Metode Penelitian Pendidikan. Bandung : Remaja Rosdakarya 